\title{
EFFICIENCY OF HERBICIDES DOSE IN MIXTURE WITH CYTOGATE FOR WEED CONTROL IN ALFALFA (MEDICAGO SATIVA L.)
}

\author{
RAOOFI, M. - ALEBRAHIM, M. T. ${ }^{*}$ \\ Department of Agronomy and Plant Breeding, Faculty of Agriculture and Natural Resources, \\ University of Mohaghegh Ardabili; Ardabil, Iran \\ (e-mail:m.raoofy@uma.ac.ir; phone:+98-919-789-1400) \\ *Corresponding author \\ e-mail:m_ebrahim@uma.ac.ir; phone:+98-912-350-1493
}

(Received 31 ${ }^{\text {st }}$ Mar 2017; accepted $19^{\text {th }}$ May 2017)

\begin{abstract}
This study aimed to evaluate the impact of surfactant on herbicide efficiency in Medicago sativa L. fields. To this end, a randomized complete block design with 10 treatments and 4 replications was used in three and four-year alfalfa fields, infested with different weeds. The treatments included the standard dose and a $20 \%$ reduced dose, a combined treatment and a control sample (weeding and no weed control). Combination of the treatments was applied along with cytogate, and included mixtures of imazethapyr and bentazon, bentazon and pyridate, and imazethapyr and pyridate, with $50 \%$ reduced dose of each herbicide. Generally, herbicides applied along with the cytogate surfactant were more efficient for weed control, as well as for an increase of the product yields, as imazethapyr herbicide along with cytogate surfactant managed to control weeds for a rate of $87.43 \%$ and increase the product yields to 93.54\%. Results showed that combination of herbicides can also be useful in controlling weeds in alfalfa fields and increasing product yields. Results also revealed that combination of bentazon and imazethapyr increased product yields to $94.47 \%$ and controlled weeds for a rate of $90.19 \%$. In addition, this method can be proposed as a means to prevent or delay probable resistance to herbicides.
\end{abstract}

Keywords: imazethapyr, bentazon, pyridate, reduced dose, surfactant

\section{Introduction}

Alfalfa as a forage crop constitutes the largest area of planting in the world (Lanini et al., 1991; 1999) as Iran (Raoofi and Giti, 2015), and it plays an important role in feeding livestock due to its high protein content (Khanjani and SoleimaniPari, 2005). More than $25 \%$ of the dry weight of alfalfa consists of fiber (Meighan et al., 2011).

Unfortunately, particular attention has not been paid to the production of this plant in Iran (Raoofi and Giti, 2015; Raoofi et al., 2013c). One of the challenges of alfalfa production is the presence of weeds (Meighani et al., 2011; Raoofi et al., 2013b). Alfalfa are particularly susceptible to weed competition because they are not vigorous competitors and weeds emerging shortly after seeding can reduce alfalfa success (Zimdahl, 2004).

Weed interference can suppress alfalfa yield (Moyer, 1985; Wilson, 1981) and impact stand densities (Becker et al., 1998). Weeds also alter the composition of the forage, increasing drying time (Doll, 1984) and reducing palatability of the alfalfa (Marten et al., 1987). Generally, weeds will cause severe competition with the crop. In addition to competition with the alfalfa, weed cause a reduction in the quality and quantity of alfalfa and decrease the price by $33 \%$ to $60 \%$ (Khanjani and SoleimaniPari, 2005; Khanjani, 2000). Similar reduction of alfalfa density due to weeds has been shown by Wilson and Burgener (2009) and Bradley et al. (2010) who reported a 20- 
$30 \%$ reduced alfalfa density through weed interference. Temme et al. (1979) found that weeds primarily were responsible for decreasing the quality of alfalfa. Frequently, weeds are comparable to alfalfa in quality; however, nutritive quality rapidly declines in weeds as they mature (Doll, 1986). Alfalfa seedlings are particularly susceptible to weed competition because they are not vigorous competitors and weeds emerging shortly after seeding can reduce alfalfa success (Fischer et al., 1988; Zimdahl, 2004). As with any crop, weed competition can reduce yields. Higher alfalfa seeding rate often resulted in greater alfalfa and total forage yield, decreased weed biomass, and increased alfalfa density (Calvin et al., 2011). Weeds interfere with alfalfa during establishment, reducing dry matter yields and plant persistence by competing for light, water, and nutrients (Fischer et al., 1988; Wolfe and Southwood, 1980; Raoofi et al., 2013d). The most damage by weeds in an alfalfa field occurs in the first harvest (Zand et al., 2010; Giti et al., 2013b), however, weeds in many areas, including Hamadan, damage all harvests (Raoofi et al., 2014b). Weed control is often accomplished by using herbicides in alfalfa fields (Myhre et al., 1998). Six herbicides are recommended for using in alfalfa (Zand et al., 2007). Effective use of herbicides is related to several factors, such as time of application, dosage, environmental conditions, method of use, desired plant, frequency of use, etc. Among the techniques to improve the performance of herbicides, use of mixed herbicides, use of integrated methods, none continuous use of one or more herbicides with the same mode of action, use of herbicides with the standard dosage at the right time, and use of additives to improve the performance of herbicides could be named.

Unfortunately, over the past few years, there have been no considerable researches on additives and the context of their use has not been provided practically by farmers. Consequently, only three additives have been recorded by the Pesticides Supervision Board in Iran.

Several herbicides are commonly used in alfalfa. Broadleaf weeds, such as thistles and Brassicaceae, are controlled with 2,4-DB. Flumetsulam and chlorimuron have also been recommended for controlling burning nettle, swinecress, and common chickweed, which are not controlled by 2,4-DB (Lopez and Romera, 1993; Tonks et al., 1991). Imazethapyr is registered for use in alfalfa and non-grazed Conservation Reserve Program lands containing legumes and forage grasses (Anonymous, 2006b). Imazethapyr reduced growth of orchardgrass when applied at the seedling stage and at first cutting (Curran et al., 1999). Paraquat applied during crop dormancy controls many emerged winter annual weeds in alfalfa (Wilson, 1997). These herbicides are safe for alfalfa, but the literature lacks published information on their safety for Dactylis glomerata. In pure orchardgrass (Dactylis glomerata), selective herbicides including 2, 4-D, clopyralid, and metsulfuron effectively control broadleaf weeds, but these herbicides cause unacceptable injury to alfalfa (Bradley et al., 2004).

Integrated weed management (IWM) is a combination of effective control methods, which reduces the weed interference to below the economic threshold (Thill et al., 1991). IWM often requires a minimum amount of herbicides (Zand et al., 2009). Evaluation of the impacts of herbicides on the environment is a necessity due to their harmful effects (Campagna, 1995). Unfortunately, the scientific application of herbicides, along with surfactants and their safety has not been studied enough to reduce the use of herbicides. The role of surfactants application were investigated by various researchers (Asmus et al., 2016; Chen et al., 2015). The interaction between the hydrophilic and lipophilic segments of adjuvants for the purpose of increasing the 
efficiency of herbicides has attracted the interest of the relevant researchers (Hall et al., 1999) and remarkable successes have been achieved in application of adjuvants for controlling pests in numerous experiments since 2002 (Zand et al., 2012). This study investigated the use of herbicides with a reduced dosage, along with a cytogate surfactant, and a combination of two herbicides with a 50\% reduction of dosage for each herbicide, in addition to the evaluation of weed control and forage production.

\section{Materials and Methods}

This experiment was conducted using a randomized complete block design in three and four-year alfalfa fields to investigate the application of chemical treatments with the standard and/or reduced doses (with and without the use of a cytogate surfactant) The study was conducted during two growing seasons of the spring and summer of 2012 and 2013, respectively. Farm under investigation, located at Km 7 Hamadan-Tehran road at latitude of $34^{\circ} 51^{\prime} \mathrm{N}$ and longitude $48^{\circ} 32^{\prime} \mathrm{E}$.

Each plot consisted of ten rows with a distance of $25 \mathrm{~cm}$ and a length of 4 meters. The distance between the two plots was $60 \mathrm{~cm}$ and the distance between the two blocks was $130 \mathrm{~cm}$. For proper evaluation, before performing treatments and concurrent with identifying plots and blocks, three fixed quadrants were installed, each with an area of one square meter per plot.

The design included the treatments with standard and reduced doses (20\%), combination treatments and a control plot (complete weeding and no weeding). The treatments were applied in two levels: the standard treatment and reduced doses with the use of a cytogate surfactant. The combination treatments consisted of a mixture of the herbicide treatment with a reduced dose of each herbicide $(50 \%)$.

The treatment included the use of Pursuit, Basagran and Lentagran herbicides as follows: Pursuit herbicide ( 0.4 1/hectare) along with cytogate surfactant $(0.32$ l/hectare), Basagran herbicide (3 1/hectare) along with cytogate surfactant $(2.41 /$ hectare $)$ and Lentagran herbicide ( $3 \mathrm{l} / \mathrm{hectare})$ along with cytogate surfactant $(2.4 \mathrm{l} / \mathrm{hectare})$. The combination treatments were prepared as a mixture of Pursuit and Basagran herbicides, Basagran and Lentagran herbicides, and Pursuit and Lentagran herbicides, in which a $50 \%$ reduced dose of each herbicide was used. In both years of the study, after a $50 \%$ flowering in each harvest, sampling took place to determine the weight of the alfalfa, as well as density and dry weight of weeds in a $50 \times 50 \mathrm{~m}$ quadrat. The dry weight of alfalfa and weeds was determined after placing the alfalfa and weed samples in the oven at $70^{\circ} \mathrm{C}$ for 48 hours. Statistical analysis software (SAS) v. 9.1 was used for analysis all data, and the obtained averages were compared by means of the LSD least significant difference test.

\section{Results}

In the study of two cuttings of established alfalfa, the following weeds were observed and identified, and their distribution levels and importance are as follows, corresponding with the findings of Khanjani and SoleimaniPari (2005) and Raoofi and Giti (2015) (Table 1). Environmental condition of the test site are expressed in Table 2, and chemical analysis of farm's soil under investigation in the Table 3. 
Table 1. Alfalfa weeds with their distribution levels and importance

\begin{tabular}{c|c|c|c}
\hline Scientific name & Family & English common name & Importance value \\
\hline Carthamus spp. & Astraceae & Safflower & $*$ \\
Centaurea spp. & Astraceae & Cornflower & $*$ \\
Ceratocephalus falcatus & Ranunculaceae & - & $*$ \\
Convolvalus arvensis $\mathrm{L}$. & Convolvulaceae & field bindweed & $*$ \\
Cuscuta spp. & cuscutacae & Small seed dodder & $* * * *$ \\
Cynodon doctylon & Poaceae & Bermuda grass & $* *$ \\
Descarainia sophia L. & Cruciferae & Hedge mustard & $* * *$ \\
Euphorbia spp. & Euphorbiaceae & Sun spurge & $*$ \\
Hordeum bulbosum L. & Poaceae & - & $*$ \\
Hordeum murinam L. & Poaceae & Mouse barley & $*$ \\
Lactuca spp. & Astraceae & Prickleylettuce & $*$ \\
Rumex crispus L. & Rosaceae & - & $* * * *$ \\
Salvia nemorosa & Lamiaceae & Violet sage & $* *$ \\
Sismbrium irio L. & Cruciferae & London rocket & $* * * *$ \\
Sorghum halepense L. & Poaceae & Johnson grass & $*$ \\
Taraxacum officinale & Astraceae & dandelion & $* *$ \\
Tragopogon spp. & Astraceae & goatsbeard & $* *$ \\
Vaccaria pyramidata & Caryophyllaceae & vaccaria & $*$ \\
Medic. & & & \\
\hline
\end{tabular}

Table 2. Environmental conditions of the test site

\begin{tabular}{c|c}
\hline Operative Measurement & Appraisal \\
\hline Absolute maximum air temperature & $36.8^{\circ} \mathrm{C}$ \\
Absolute minimum air temperature & $-29.6^{\circ} \mathrm{C}$ \\
Average air temperature & $9.6^{\circ} \mathrm{C}$ \\
The hottest months of the year & $\mathrm{July}$ and August \\
Therage air temperature of hottest months of the year & $35^{\circ} \mathrm{C}$ \\
The Coldest months of the year & December and junuary \\
Average air temperature of coldest months of the year & $-25.4^{\circ} \mathrm{C}$ \\
The annual amount of precipitation & 300 ml. \\
The number of frost days & 143 Days \\
Wind direction & multifarious \\
\hline
\end{tabular}

Table 3. Chemical analysis of farm's soil

\begin{tabular}{c|c|c|c|c|c|c|c|c|c|c}
\hline $\begin{array}{c}\text { Soil } \\
\text { contexture }\end{array}$ & $\begin{array}{c}\text { Sand } \\
(\boldsymbol{\%})\end{array}$ & $\begin{array}{c}\text { Silt } \\
(\boldsymbol{\%})\end{array}$ & $\begin{array}{c}\text { Clay } \\
(\boldsymbol{\%})\end{array}$ & $\begin{array}{c}\text { Potassium } \\
\text { absorbable } \\
(\mathbf{p p m})\end{array}$ & $\begin{array}{c}\text { Phosphor } \\
\text { absorbable } \\
(\mathbf{p p m})\end{array}$ & $\begin{array}{c}\text { Organic } \\
\text { carbon } \\
(\boldsymbol{\%})\end{array}$ & $\begin{array}{c}\text { Epicene } \\
\text { material } \\
(\boldsymbol{\%})\end{array}$ & $\mathbf{P H}$ & $\begin{array}{c}\text { EC } \\
(\mathbf{d s} / \mathbf{m})\end{array}$ & $\begin{array}{c}\text { Depth of } \\
\text { sampling } \\
(\mathbf{c m})\end{array}$ \\
\hline Silty loamy & 33 & 40 & 27 & 332.9 & 26.4 & 0.58 & 9.5 & 7.6 & 0.298 & 30 \\
\hline
\end{tabular}

In this two-year field study, the following weeds were identified in high-density fractions: normal flixweed (Descarainia sophia L.), sorrel (Rumex crispus L.), bitter flixweed (Sisimbrium irio L.), dandelion (Taraxacum officinalis) and salsify (Tragopogon spp.). These weeds function as the main weeds in alfalfa fields. The effect of the treatments on weed density in all the four of the alfalfa harvests was significant at 
a level of 1\% (Table 4). The comparison of the average of the treatments with the density of five identified weeds in the first harvest (Table 5) showed that the reduced treatment with cytogate and also, the integrated Pursuit and Basagran treatment had the best weed control on bitter flixweed. These results were also consistent with the results of Raoofi and Giti (2015). Normal flixweed was significantly controlled by the use of Pursuit treatments in standard doses, reduced dose of Pursuit along with cytogate, reduced dose of Basagran along with cytogate and combination of Basagran and Pursuit with a 50\% reduced dose. It was found that the cytogate consumption as a good surfactant could increase the efficiency of herbicides and decrease their consumption down to $20 \%$. The use of two herbicides, in combination with cytogate, delays the resistance to herbicides in weeds, and therefore, it is highly recommended, since one most important issue regarding herbicide use is cross and multiple resistance (Zand and Baghestani, 2002).

In the investigation of sorrel control in the first harvest, the Pursuit treatments with the standard and reduced doses along with cytogate and also, Pursuit combined with Basagran were analyzed and included in the group with the lowest density of sorrel. Also, in the first harvest, salsify was affected by the Pursuit treatment with the standard dose and had the lowest density. The first harvest of dandelion had the greatest impact from the treatment with a reduced dose of Pursuit along with cytogate and treatment with a combination of Pursuit and Basagran. Raoofi et al. (2013a) also stated that Pursuit along with cytogate is one of the best treatments for broadleaf weed control and can significantly reduce dandelion density. Moreover, Raoofi et al. (2014a) stated that surfactant consumption can significantly reduce the amount of pesticides. Researchers including Ozkan et al. (1993) have evaluated the effects of adjuvants on the performance of pesticide sprays. Some studies have shown that a number of polymers enjoy the ability of breaking down after leaving the sprayer pump in the same way that this process takes place in the return action through the lateral route or hydraulic mixers in ordinary sprayers (Zhu et al., 1997). Comparison of the treatment results in the second harvest (Table 5) showed that the best option to control bitter flixweed was the same as the option in the first harvest. The only difference was that the reduced dose of Basagran and accompanying cytogate, the Pursuit and accompanying cytogate treatment and a reduced dose of the combined Pursuit-Basagran were all placed in the same statistical group. These results point to the possibility of reducing the dose of herbicide. Gressel and Segel (1990a, 1990b) also emphasized reducing the use of this herbicide to 0.1 in the standard dose along with the cytogate surfactant. The results of the second harvest and control of normal flixweed were fully compatible with the first harvest. Sorrel, in the second harvest, had the largest decline using the Pursuit treatment with standard and reduced doses along with cytogate, and also the reduced dose of Basagran with cytogate and the Pursuit and Basagran combination. Investigation of the salsify weed density in the second harvest revealed that both the reduced doses of Pursuit and Basagran with cytogate surfactant along with the Pursuit-Basagran combination treatment were placed in the same group. The results of the second harvest for dandelion were fully in accordance with the first harvest results. It was found that the weed density in the second harvest had an exponential decline compared to the first harvest, but the presence of weeds was still evident in the second harvest. It should be noted that the decline of normal and bitter flixweed in the second harvest could have been related to the first harvest due to the cutting of their roots. 
Table 4. Analysis of variance of the density and dry weight of weeds in each forth harvests. $n s,{ }^{*}$ and $* *$ are insignificant and significant at confidence level of $1 \%$ and $5 \%$, respectively

\begin{tabular}{c|c|c|c|c|c|c|c|c|c}
\hline \multicolumn{1}{|c|}{$\begin{array}{c}\text { The source } \\
\text { of changes }\end{array}$} & $\begin{array}{c}\text { Degrees } \\
\text { of } \\
\text { freedom }\end{array}$ & $\begin{array}{c}\text { Harvest } \\
\text { density } \\
\text { (first) }\end{array}$ & $\begin{array}{c}\text { Harvest } \\
\text { density(second) }\end{array}$ & $\begin{array}{c}\text { Mean of squares } \\
\text { Hensity(third) }\end{array}$ & $\begin{array}{c}\text { Harvest } \\
\text { density(forth) }\end{array}$ & $\begin{array}{c}\text { Dry } \\
\text { weight } \\
\text { (first } \\
\text { harvest) }\end{array}$ & $\begin{array}{c}\text { Dry weight } \\
\text { (second } \\
\text { harvest) }\end{array}$ & $\begin{array}{c}\text { Dry } \\
\text { weight } \\
\text { (third } \\
\text { harvest) }\end{array}$ & $\begin{array}{c}\text { Dry weight } \\
\text { (forth } \\
\text { harvest) }\end{array}$ \\
\hline Block & 3 & $1.66^{\mathrm{ns}}$ & $1.93^{\mathrm{ns}}$ & $1.39^{\mathrm{ns}}$ & $1.66^{\mathrm{ns}}$ & $0.88^{\mathrm{ns}}$ & $1.68^{\mathrm{ns}}$ & $1.11^{\mathrm{ns}}$ & $0.87^{\mathrm{ns}}$ \\
Treatment & 9 & $109.210^{* *}$ & $111.210^{* *}$ & $118.210^{* *}$ & $108.210^{* *}$ & $476.6^{* *}$ & $745.7^{* *}$ & $848.4^{* *}$ & $518.3^{* *}$ \\
Errors & 27 & 18.8 & 19.12 & 12.42 & 11.44 & 22.32 & 21.24 \\
CV & & 4.11 & 3.97 & 4.94 & 3.88 & 5.96 & 24.02 \\
\hline
\end{tabular}

Table 5. The average of weeds density in the first and second harvest during two years. In each column, the average that at least one common letter are not significantly different

\begin{tabular}{|c|c|c|c|c|c|c|c|c|c|c|}
\hline \multirow{2}{*}{ Treatment } & \multicolumn{2}{|c|}{$\begin{array}{l}\text { Bitter flixweed } \\
\left(\text { plants } / \mathbf{m}^{2}\right)\end{array}$} & \multicolumn{2}{|c|}{$\begin{array}{l}\text { Normal flixweed } \\
\quad\left(\text { plants } / \mathbf{m}^{2}\right)\end{array}$} & \multicolumn{2}{|c|}{$\begin{array}{r}\text { Sorrel } \\
\left(\text { plants } / \mathbf{m}^{2}\right)\end{array}$} & \multicolumn{2}{|c|}{$\begin{array}{c}\text { Salsify } \\
(\text { stem/mon } \\
\end{array}$} & \multicolumn{2}{|c|}{$\begin{array}{l}\text { Dandelion } \\
\left(\text { stem } / \mathbf{m}^{2}\right)\end{array}$} \\
\hline & $\begin{array}{c}\text { Harvest } \\
1\end{array}$ & $\begin{array}{l}\text { Harvest } \\
2\end{array}$ & $\begin{array}{c}\text { Harvest } \\
1\end{array}$ & $\begin{array}{l}\text { Harvest } \\
2\end{array}$ & $\begin{array}{c}\text { Harvest } \\
1\end{array}$ & $\begin{array}{l}\text { Harvest } \\
2\end{array}$ & $\begin{array}{c}\text { Harvest } \\
1\end{array}$ & $\begin{array}{l}\text { Harvest } \\
2\end{array}$ & $\begin{array}{c}\text { Harvest } \\
1\end{array}$ & $\begin{array}{l}\text { Harvest } \\
2\end{array}$ \\
\hline Pursuit 0.4 1/hectare & $2.5^{\mathrm{e}}$ & $2.8^{\mathrm{d}}$ & $3.4^{\mathrm{e}}$ & $2.9^{\mathrm{e}}$ & $2.4^{\mathrm{e}}$ & $2.2^{\mathrm{e}}$ & $1.4^{\mathrm{f}}$ & $3.5^{\mathrm{e}}$ & $3.2^{f}$ & $2.8^{\mathrm{f}}$ \\
\hline Basagran 3 1/hectare & $3.6^{\mathrm{d}}$ & $2.9^{\mathrm{d}}$ & $5.1^{\mathrm{d}}$ & $4.4^{\mathrm{d}}$ & $3.7^{\mathrm{d}}$ & $3.2^{\mathrm{d}}$ & $5.9^{\mathrm{d}}$ & $5.3^{\mathrm{d}}$ & $4.1^{\mathrm{e}}$ & $3.6^{\mathrm{e}}$ \\
\hline Lentagran 3 1/hectare & $10.5^{\mathrm{b}}$ & $9.5^{\mathrm{b}}$ & $13.5^{\mathrm{b}}$ & $13.1^{\mathrm{b}}$ & $11.8^{\mathrm{b}}$ & $10.6^{\mathrm{b}}$ & $12.6^{\mathrm{b}}$ & $11.5^{\mathrm{b}}$ & $9.9^{\mathrm{c}}$ & $8.9^{\mathrm{c}}$ \\
\hline Pursuit $0.321 /$ hectare & $1.4^{\mathrm{f}}$ & $1.1^{\mathrm{e}}$ & $3.1^{\mathrm{ef}}$ & $2.8^{\mathrm{e}}$ & $1.9^{\mathrm{e}}$ & $1.8^{\mathrm{e}}$ & $3.1^{\mathrm{e}}$ & $2.7^{\mathrm{f}}$ & $1.9^{\mathrm{g}}$ & $1.6^{\mathrm{g}}$ \\
\hline Basagran 2.4 1/hectare & $2.3^{\mathrm{e}}$ & $1.9^{\mathrm{e}}$ & $3.1^{\mathrm{ef}}$ & $2.6^{\mathrm{e}}$ & $3.4^{\mathrm{d}}$ & $1.9^{\mathrm{e}}$ & $3.4^{\mathrm{e}}$ & $2.9^{\mathrm{f}}$ & $3.2^{\mathrm{f}}$ & $2.8^{\mathrm{f}}$ \\
\hline $\begin{array}{l}\text { Pursuit } 0.2 \text { 1/hectare +Basagran } 1.5 \\
\text { 1/hectare }\end{array}$ & $1.4^{\mathrm{f}}$ & $1.1^{\mathrm{e}}$ & $3.2^{\mathrm{ef}}$ & $2.8^{\mathrm{e}}$ & $2.2^{\mathrm{e}}$ & $1.6^{\mathrm{e}}$ & $2.9^{\mathrm{e}}$ & $2.8^{\mathrm{f}}$ & $2.1^{\mathrm{g}}$ & $1.7^{\mathrm{g}}$ \\
\hline $\begin{array}{l}\text { Pursuit } 0.2 \text { 1/hectare +Lentagran } 1.5 \\
\text { 1/hectare }\end{array}$ & $11.1^{\mathrm{b}}$ & $10.8^{\mathrm{b}}$ & $14.2^{\mathrm{b}}$ & $13.3^{\mathrm{b}}$ & $12.1^{\mathrm{b}}$ & $10.7^{\mathrm{b}}$ & $13.9^{\mathrm{a}}$ & $13.2^{\mathrm{a}}$ & $11.3^{\mathrm{b}}$ & $10.1^{\mathrm{b}}$ \\
\hline $\begin{array}{l}\text { Basagran } 1.51 / \text { hectare +Lentagran } 1.5 \\
\text { 1/hectare }\end{array}$ & $11^{\mathrm{b}}$ & $9.6^{\mathrm{b}}$ & $14.2^{\mathrm{b}}$ & $12.9^{\mathrm{b}}$ & $12.1^{b}$ & $10.1^{\mathrm{b}}$ & $14.2^{\mathrm{a}}$ & $11.5^{b}$ & $10.5^{\mathrm{c}}$ & $9.4^{\mathrm{c}}$ \\
\hline Weedy & $14.5^{\mathrm{a}}$ & $14.1^{\mathrm{a}}$ & $17.3^{\mathrm{a}}$ & $15.7^{\mathrm{a}}$ & $14.8^{\mathrm{a}}$ & $13.1^{\mathrm{a}}$ & $14.4^{\mathrm{a}}$ & $13.5^{\mathrm{a}}$ & $13.8^{\mathrm{a}}$ & $12.4^{\mathrm{a}}$ \\
\hline
\end{tabular}


One of the non-chemical methods of weed control mentioned by Khanjani and SoleimaniPari (2005) is root cutting in the alfalfa field. According to the literature, there is no e investigation on sensitivity, tolerance or resistance of weeds to root cutting, except for grass at different growth stages (McCarthy et al., 2001). Thus, this study should be replicated on other weeds. The harvesting of alfalfa causes root cutting of the flixweed and thus, can be very effective in reducing flixweed density.

Alternation and repetition of eradication techniques, along with actions such as application of herbicides can increase the effectiveness of weed control. Accordingly, Ghorbani et al. (2009) stated that harvesting and eradicating accompanied with chemical pesticides improve the ability to control weeds. The two weed types, bitter and normal flixweed, were obviously reduced in the third harvest compared to the first and second harvest; however, some weeds still remained on the farm.

The results obtained from the third harvest conformed to the two previous harvests and revealed the favorable effect of the Pursuit and accompanying cytogate treatment. In fact, the controlling effect of the Pursuit and accompanying cytogate treatment was observed even after the study period. Comparison of the means of the experimental treatments on normal flixweed in the third harvest showed that the three Lentagran treatments with standard dose, Pursuit and Basagran with reduced dose and accompanying cytogate were placed in the same statistical group. Pursuit treatments with standard dose, Pursuit with reduced dose and accompanying cytogate and Basagran with reduced dose and accompanying cytogate, were the best and most successful treatments for sorrel weed control in the third harvest. The best treatments for salsify weed control in the third harvest were treatments with reduced herbicide dose, so that both Pursuit and Basagran treatments with reduced dose and accompanying cytogate had the greatest impact and were located in the same statistical group. Also, the reduced dose of Pursuit and accompanying cytogate consumption had a highly positive effect on controlling the dandelion weed in the third harvest (Table 6). This treatment also acted favorably in controlling dandelion in the first and second harvests. The study results were also in conformity with Beckie and Morrison's (1993) results and revealed that the reduced doses can be used in weed management if another agent compensates for such dose reduction. Application of Cytogate as an adjuvant in the chemical control of weeds on Alfalfa (Medicago sativa L.) has been evaluated before, and its synergistic effects have been confirmed (Raoofi and Giti, 2015; Giti et al., 2013b).

The results obtained from comparison of the means of the treatments in the fourth harvest (Table 6) showed that the best options for bitter flixweed control were Pursuit and Basagran treatments, both with a reduced dose and accompanying cytogate. Also, Lentagran treatment with the standard dose, as well as Pursuit and Basagran both with a reduced dose and accompanying cytogate were the best options for normal flixweed control. It should be noted that the problem of bitter and normal flixweed in the fourth harvest was almost insignificant and negligible. Existence of so little density of bitter and normal flixweed in the fourth harvest has been proven by Raoofi and Giti (2012), Khanjani and SoleimaniPari (2005) and Giti et al. (2013a). In a study on the density of these two weeds from the first harvest to the fourth, it was observed that, in the fourth harvest, the weed problem 
was nearly resolved and thus, there was little density of the two weeds in the control (no weeding). The density reduction in the two weeds can be related to eradication of these two weeds resulted from each harvest and passage of the growing season for the weeds, as well as the application of the experimental treatments. The Pursuit treatment accompanied with cytogate in the fourth harvest was introduced as the best option to control sorrel and dandelion weeds. Also, consumption of Basagran with a reduced dose and accompanying cytogate surfactant could transcend the other treatments to control the salsify weed in the fourth harvest.

The results obtained from variance analysis related to the dry weight of weeds showed that all the applied experimental treatments were statistically significant at the level of $1 \%$ in all the four harvests (Table 4). The results of the comparison of the means of dry weight in the first harvest, considering separated species, Table 7 showed that the best choice for reducing the dry weight of bitter flixweed was the Pursuit treatment with reduced dose along with cytogate, as well asthe combination treatment of Pursuit and Basagran. Also, Pursuit with reduced dose along with cytogate caused the lowest dry weight of normal flixweed in the first harvest. Investigating the dry weight of sorrel in the first harvest, Pursuit and Basagran treatments, both with reduced dose along with cytogate, and also the combination treatment of Pursuit and Basagran were all in the same statistical group, and were the best treatments for reducing the dry weight of this weed. Pursuit treatment with reduced dose along with cytogate and the combination treatment of Pursuit and Basagran in the fourth harvest were in the same statistical group containing the lowest dry weight of salsify. The Pursuit treatment with reduced dose accompanied with cytogate consumption was the best option to reduce the dry weight of dandelion in the first harvest. Raoofi and Giti (2015) have also recommended these treatments for reducing the weed dry weight.

The results obtained from comparison of the means of the dry weight characteristic in the second harvest, considering separated species, (Table 7) showed that the best options for reducing the dry weight of bitter flixweed were the Pursuit and Basagran treatments, both with reduced dose and accompanying cytogate. The combined treatment of Pursuit and Basagran was placed in the same statistical group. The obtained results showed that no antagonistic effects were observed as a result of the combination of the two above-mentioned herbicides. The Pursuit treatment with standard dose and reduced dose accompanied with cytogate along with the Basagran treatment with reduced dose accompanied with cytogate caused the lowest dry weight of normal flixweed (Table 7). Investigating the dry weight of sorrel in the second harvest, Pursuit and Basagran treatments with standard dose and Pursuit and Basagran treatments with reduced dose and associated cytogate were in the same statistical group with the minimum weight of dry sorrel. The Pursuit and Basagran treatments with standard dose and Pursuit and Basagran treatments with reduced dose and associated cytogate, as well as the combined treatment of Pursuit and Basagran all led to a minimum dry weight of salsify in the second harvest. The Pursuit treatment with reduced dose and associated cytogate, and also the combined Pursuit and Basagran treatment were the best choices for reducing the dry weight of dandelion in the second harvest. Existence of bitter and normal flixweed dry matter in the third harvest was almost insignificant and negligible; however, among the experimental treatments, the 
treatments of Pursuit and Basagran, both with reduced doses and associated cytogate and weed control treatment contained the lowest dry weight of bitter flixweed and thus, were placed in the same statistical group. Lentagran treatment with the standard dose along with the Pursuit and Basagran treatments, both with decreased doses and accompanying cytogate consumption, caused the lowest dry weight of normal flixweed in the second harvest. In the study of sorrel dry weight in the third harvest, the Pursuit and Basagran treatments with the standard dose, as well as the Pursuit and Basagran, both with reduced dose and associated cytogate, were revealed as the best treatments to reduce sorrel. Effective treatments to control salsify in the third harvest were consistent with the effective treatments to control sorrel, with the difference that the incorporated Pursuit and Basagran treatment associated with the above-mentioned treatments was placed in the same statistical group. Basagran, with both standard and reduced dose as well as associated cytogate, along with Pursuit with standard and decreased dose, as well as accompanying cytogate were the best treatments for reducing the dandelion dry weight in the third harvest.

Mamnooie and Shimi (2012) and Meighani et al. (2011) have also shown that the application of the Pursuit herbicide in alfalfa fields caused significant reduction in weed dry weight. Results of a comparison of the weed dry weight characteristic, considering separated species, in the fourth harvest (Table 8) revealed a significant decrease in most of the weeds. A further reduction was observed in both the bitter and normal flixweed, and there was almost no interference problem related to the bitter and normal flixweed in the fourth harvest. However, some weeds were still observed in the fourth harvest. Sorrel, salsify, and dandelion weeds continued to exist until the fourth harvest, because their growth season still caused damage until the late summer. The Pursuit and Basagran treatments, both with standard dose, reduced dose and associated cytogate consumption, caused the lowest sorrel dry weight in the fourth harvest. Also, salsify, as the result of the Basagran treatment with reduced dose and accompanying cytogate consumption had the lowest dry weight in the fourth harvest. Effective treatments on dandelion dry weight reduction in the fourth harvest included the Pursuit and Basagran treatments with standard dose, reduced dose and associated cytogate, which were in the same statistical group. The results of density analysis and alfalfa dry weight in all the four harvests showed that, at the level of $1 \%$, application of the treatment had a significant effect on this characteristic (Table 9). The comparison of the means of the experimental treatments showed that the treatments exertion were significantly different from each other, so that from the first harvest until the third harvest, after blank treatment (hand weeding), the Pursuit treatment with reduced dose and associated cytogate consumption accounted for the highest density of alfalfa and was considered the best treatment. 
Table 6. The average of weeds density in the third and fourth harvest during two years. In each column, the average that at least one common letter are not significantly different

\begin{tabular}{|c|c|c|c|c|c|c|c|c|c|c|}
\hline \multirow{2}{*}{ Treatment } & \multicolumn{2}{|c|}{$\begin{array}{l}\text { Bitter flixweed } \\
\left(\text { plants } / \mathbf{m}^{2}\right)\end{array}$} & \multicolumn{2}{|c|}{$\begin{array}{l}\text { Normal flixweed } \\
\quad\left(\text { plants } / \mathbf{m}^{2}\right)\end{array}$} & \multicolumn{2}{|c|}{$\begin{array}{c}\text { Sorrel } \\
\left(\text { plants } / \mathbf{m}^{2}\right)\end{array}$} & \multicolumn{2}{|c|}{$\begin{array}{c}\text { Salsify } \\
\text { (stem/m²) }\end{array}$} & \multicolumn{2}{|c|}{$\begin{array}{c}\text { Dandelion } \\
\left(\mathbf{s t e m} / \mathbf{m}^{2}\right)\end{array}$} \\
\hline & $\begin{array}{c}\text { Harvest } \\
\mathbf{3} \\
\end{array}$ & \begin{tabular}{|c|c} 
Harvest \\
4
\end{tabular} & $\begin{array}{c}\text { Harvest } \\
\mathbf{3} \\
\end{array}$ & \begin{tabular}{|c} 
Harvest \\
$\mathbf{4}$
\end{tabular} & $\begin{array}{c}\text { Harvest } \\
\mathbf{3}\end{array}$ & $\begin{array}{c}\text { Harvest } \\
4\end{array}$ & $\begin{array}{c}\text { Harvest } \\
\mathbf{3}\end{array}$ & $\begin{array}{c}\text { Harvest } \\
4\end{array}$ & $\begin{array}{c}\text { Harvest } \\
\mathbf{3}\end{array}$ & $\begin{array}{c}\text { Harvest } \\
4\end{array}$ \\
\hline Pursuit 0.4 1/hectare & $0.1^{\mathrm{c}}$ & $0.06^{\mathrm{b}}$ & $0.05^{\mathrm{e}}$ & $0.01^{\mathrm{b}}$ & $1.61^{\mathrm{e}}$ & $1.18^{\mathrm{d}}$ & $2.25^{\mathrm{e}}$ & $1.79^{\mathrm{f}}$ & $2.11^{\mathrm{e}}$ & $1.46^{\mathrm{d}}$ \\
\hline Basagran 3 1/hectare & $0.26^{\mathrm{b}}$ & $0.03^{\mathrm{c}}$ & $0.02^{\mathrm{c}}$ & $0.01^{\mathrm{b}}$ & $2.33^{\mathrm{d}}$ & $1.62^{\mathrm{d}}$ & $3.38^{\mathrm{d}}$ & $2.41^{\mathrm{e}}$ & $2.71^{\mathrm{e}}$ & $1.79^{\mathrm{d}}$ \\
\hline Lentagran 3 1/hectare & $0.33^{\mathrm{d}}$ & $0.01^{\mathrm{e}}$ & $0^{\mathrm{f}}$ & $0^{\mathrm{d}}$ & $2.71^{\mathrm{d}}$ & $5.19^{\mathrm{b}}$ & $8.09^{\mathrm{b}}$ & $5.5^{\mathrm{c}}$ & $6.61^{\mathrm{c}}$ & $4.36^{\mathrm{b}}$ \\
\hline Pursuit 0.32 1/hectare & $0^{\mathrm{e}}$ & $0^{\mathrm{f}}$ & $0^{\mathrm{f}}$ & $0^{\mathrm{d}}$ & $1.21^{\mathrm{e}}$ & $0.77^{\mathrm{e}}$ & $1.87^{\mathrm{f}}$ & $1.47^{\mathrm{f}}$ & $1.14^{\mathrm{t}}$ & $0.78^{\mathrm{e}}$ \\
\hline Basagran 2.4 1/hectare & $0.02^{\mathrm{d}}$ & $0^{\mathrm{f}}$ & $0^{\mathrm{f}}$ & $0^{\mathrm{d}}$ & $1.91^{\mathrm{e}}$ & $1.09^{\mathrm{d}}$ & $1.36^{\mathrm{f}}$ & $0.99^{\mathrm{g}}$ & $2.17^{\mathrm{e}}$ & $1.44^{\mathrm{d}}$ \\
\hline Lentagran 2.4 1/hectare & $0.1^{\mathrm{c}}$ & $0.03^{\mathrm{c}}$ & $0.1^{\mathrm{d}}$ & $0.01^{\mathrm{b}}$ & $6.62^{\mathrm{c}}$ & $4.57^{\mathrm{c}}$ & $6.21^{\mathrm{c}}$ & $4.33^{\mathrm{d}}$ & $5.69^{\mathrm{d}}$ & $3.66^{\mathrm{c}}$ \\
\hline Pursuit 0.2 1/hectare +Basagran 1.5 1/hectare & $0.26^{\mathrm{b}}$ & $0.01^{\mathrm{e}}$ & $0.1^{\mathrm{d}}$ & $0.01^{\mathrm{b}}$ & $7.71^{\mathrm{b}}$ & $5.4^{\mathrm{b}}$ & $8.79^{\mathrm{b}}$ & $6.09^{\mathrm{b}}$ & $7.1^{\mathrm{b}}$ & $4.21^{\mathrm{b}}$ \\
\hline Pursuit 0.2 1/hectare +Lentagran 1.5 1/hectare & $0.29^{\mathrm{b}}$ & $0.03^{\mathrm{d}}$ & $0.6^{\mathrm{b}}$ & $0.01^{\mathrm{b}}$ & $7.92^{\mathrm{b}}$ & $5.51^{\mathrm{b}}$ & $8.39^{\mathrm{b}}$ & $5.52^{\mathrm{c}}$ & $6.63^{\mathrm{c}}$ & $4.33^{\mathrm{b}}$ \\
\hline Basagran 1.5 1/hectare +Lentagran 1.5 1/hectare & $0.29^{\mathrm{b}}$ & $0.02^{\mathrm{d}}$ & $0.1^{\mathrm{d}}$ & $0.06^{\mathrm{a}}$ & $7.76^{\mathrm{b}}$ & $5.49^{\mathrm{b}}$ & $8.23^{\mathrm{b}}$ & $5.47^{\mathrm{c}}$ & $5.4^{\mathrm{d}}$ & $4.19^{\mathrm{b}}$ \\
\hline Weedy & $1.4^{\mathrm{a}}$ & $0.08^{\mathrm{a}}$ & $1.8^{\mathrm{a}}$ & $0.06^{\mathrm{a}}$ & $11.59^{\mathrm{a}}$ & $10.81^{\mathrm{a}}$ & $10.97^{\mathrm{a}}$ & $11.61^{\mathrm{a}}$ & 12.66 & $11.961^{\mathrm{a}}$ \\
\hline
\end{tabular}

Table 7. The average of dry weight of weeds in the first and second harvest during two years. In each column, the average that at least one common letter are not significantly different ( $L S D \alpha=5 \%)$

\begin{tabular}{|c|c|c|c|c|c|c|c|c|c|c|}
\hline & \multirow{2}{*}{\multicolumn{2}{|c|}{$\begin{array}{c}\text { Dandelion } \\
\left(\mathrm{stem} / \mathbf{m}^{2}\right) \\
\end{array}$}} & \multirow{2}{*}{\multicolumn{2}{|c|}{$\begin{array}{c}\text { Salsify } \\
\left(\text { stem/m } \mathbf{m}^{2}\right)\end{array}$}} & \multirow{2}{*}{\multicolumn{2}{|c|}{$\begin{array}{c}\text { Sorrel } \\
\left(\text { plants } / \mathbf{m}^{2}\right)\end{array}$}} & \multirow{2}{*}{\multicolumn{2}{|c|}{$\begin{array}{c}\text { Normal flixweed } \\
\left(\text { plants } / \mathbf{m}^{2}\right)\end{array}$}} & \multirow{2}{*}{\multicolumn{2}{|c|}{$\begin{array}{c}\text { Bitter flixweed } \\
\left(\text { plants } / \mathbf{m}^{2}\right) \\
\end{array}$}} \\
\hline & & & & & & & & & & \\
\hline Treatment & $\begin{array}{c}\text { Harvest } \\
1 \\
\end{array}$ & $\begin{array}{c}\text { Harvest } \\
2 \\
\end{array}$ & $\begin{array}{c}\text { Harvest } \\
1 \\
\end{array}$ & $\begin{array}{c}\text { Harvest } \\
2 \\
\end{array}$ & $\begin{array}{c}\text { Harvest } \\
1 \\
\end{array}$ & $\begin{array}{c}\text { Harvest } \\
1 \\
\end{array}$ & $\begin{array}{c}\text { Harvest } \\
2 \\
\end{array}$ & $\begin{array}{c}\text { Harvest } \\
1 \\
\end{array}$ & $\begin{array}{c}\text { Harvest } \\
2 \\
\end{array}$ & $\begin{array}{c}\text { Harvest } \\
1 \\
\end{array}$ \\
\hline Pursuit $0.41 /$ hectare & $0 / 55^{\mathrm{cd}}$ & $0 / 48^{d}$ & $0 / 63^{\mathrm{d}}$ & $0 / 78^{c}$ & $0 / 39^{d}$ & $0 / 78^{c}$ & $0 / 52^{\mathrm{de}}$ & $0 / 53^{\mathrm{e}}$ & $0 / 64^{c}$ & $0 / 45^{\mathrm{e}}$ \\
\hline Basagran 3 1/hectare & $0 / 56^{\mathrm{cd}}$ & $0 / 59^{c}$ & $0 / 99^{\text {cd }}$ & $0 / 87^{\mathrm{c}}$ & $0 / 84^{\text {cd }}$ & $0 / 55^{\mathrm{d}}$ & $0 / 87^{\mathrm{d}}$ & $0 / 86^{\mathrm{d}}$ & $0 / 66^{\mathrm{c}}$ & $0 / 63^{\mathrm{d}}$ \\
\hline Lentagran 3 1/hectare & $1 / 7^{\mathrm{b}}$ & $1 / 73^{b}$ & $2 / 15^{\mathrm{a}}$ & $1 / 96^{\mathrm{b}}$ & $1 / 87^{\mathrm{b}}$ & $1 / 88^{\mathrm{b}}$ & $2 / 14^{\mathrm{b}}$ & $2 / 33^{b}$ & $1 / 81^{\mathrm{b}}$ & $1 / 92^{\mathrm{b}}$ \\
\hline Pursuit $0.321 /$ hectare & $0 / 29^{\mathrm{e}}$ & $0 / 24^{\mathrm{e}}$ & $0 / 49^{d}$ & $0 / 41^{\mathrm{d}}$ & $0 / 4^{\mathrm{d}}$ & $0 / 32^{\mathrm{e}}$ & $0 / 49^{\mathrm{de}}$ & $0 / 36^{\mathrm{f}}$ & $0 / 13^{d}$ & $0 / 17^{\mathrm{f}}$ \\
\hline
\end{tabular}


Basagran 2.4 1/hectare

Lentagran 2.4 1/hectare

Pursuit 0.2 1/hectare +Basagran 1.5

$1 /$ hectare

Pursuit 0.2 1/hectare +Lentagran 1.5

$1 /$ hectare

Basagran 1.5 1/hectare +Lentagran 1.5

1/hectare

Weedy

\begin{tabular}{c|c|c|c|c|c|c|c|c|c}
$0 / 51^{\mathrm{b}}$ & $0 / 57^{\mathrm{c}}$ & $0 / 5^{\mathrm{d}}$ & $0 / 79^{\mathrm{c}}$ & $0 / 43^{\mathrm{d}}$ & $0 / 32^{\mathrm{e}}$ & $0 / 33^{\mathrm{e}}$ & $0 / 51^{\mathrm{e}}$ & $0 / 18^{\mathrm{d}}$ & $0 / 43^{\mathrm{e}}$ \\
$1 / 66^{\mathrm{b}}$ & $1 / 83^{\mathrm{b}}$ & $1 / 71^{\mathrm{b}}$ & $1 / 89^{\mathrm{b}}$ & $1 / 77^{\mathrm{b}}$ & $1 / 81^{\mathrm{b}}$ & $1 / 77^{\mathrm{c}}$ & $1 / 88^{\mathrm{c}}$ & $1 / 42^{\mathrm{b}}$ & $1 / 46^{\mathrm{bc}}$ \\
$0 / 3^{\mathrm{e}}$ & $0 / 54^{\mathrm{c}}$ & $0 / 49^{\mathrm{d}}$ & $0 / 42^{\mathrm{d}}$ & $0 / 29^{\mathrm{e}}$ & $0 / 33^{\mathrm{e}}$ & $0 / 59^{\mathrm{d}}$ & $0 / 56^{\mathrm{e}}$ & $0 / 15^{\mathrm{d}}$ & $0 / 20^{\mathrm{f}}$ \\
$1 / 67^{\mathrm{b}}$ & $1 / 76^{\mathrm{b}}$ & $2 / 2^{\mathrm{a}}$ & $2 / 49^{\mathrm{a}}$ & $1 / 88^{\mathrm{b}}$ & $1 / 83^{\mathrm{b}}$ & $2 / 6^{\mathrm{b}}$ & $2 / 42^{\mathrm{b}}$ & $1 / 87^{\mathrm{b}}$ & $1 / 90^{\mathrm{b}}$ \\
$1 / 68^{\mathrm{b}}$ & $1 / 72^{\mathrm{b}}$ & $2 / 19^{\mathrm{a}}$ & $1 / 99^{\mathrm{b}}$ & $1 / 89^{\mathrm{b}}$ & $1 / 85^{\mathrm{b}}$ & $2 / 35^{\mathrm{b}}$ & $2 / 36^{\mathrm{b}}$ & $1 / 83^{\mathrm{b}}$ & $1 / 83^{\mathrm{b}}$ \\
$2 / 11^{\mathrm{a}}$ & $2 / 17^{\mathrm{a}}$ & $2 / 17^{\mathrm{a}}$ & $2 / 51^{\mathrm{a}}$ & $2 / 33^{\mathrm{a}}$ & $2 / 46^{\mathrm{a}}$ & $3 / 88^{\mathrm{a}}$ & $2 / 85^{\mathrm{a}}$ & $2 / 52^{\mathrm{a}}$ & $2 / 87^{\mathrm{a}}$
\end{tabular}

Table 8. The average of dry weight of weeds in the third and fourth harvest during two years. In each column, the average that at least one common letter are not significantly different ( $L S D \alpha=5 \%$ )

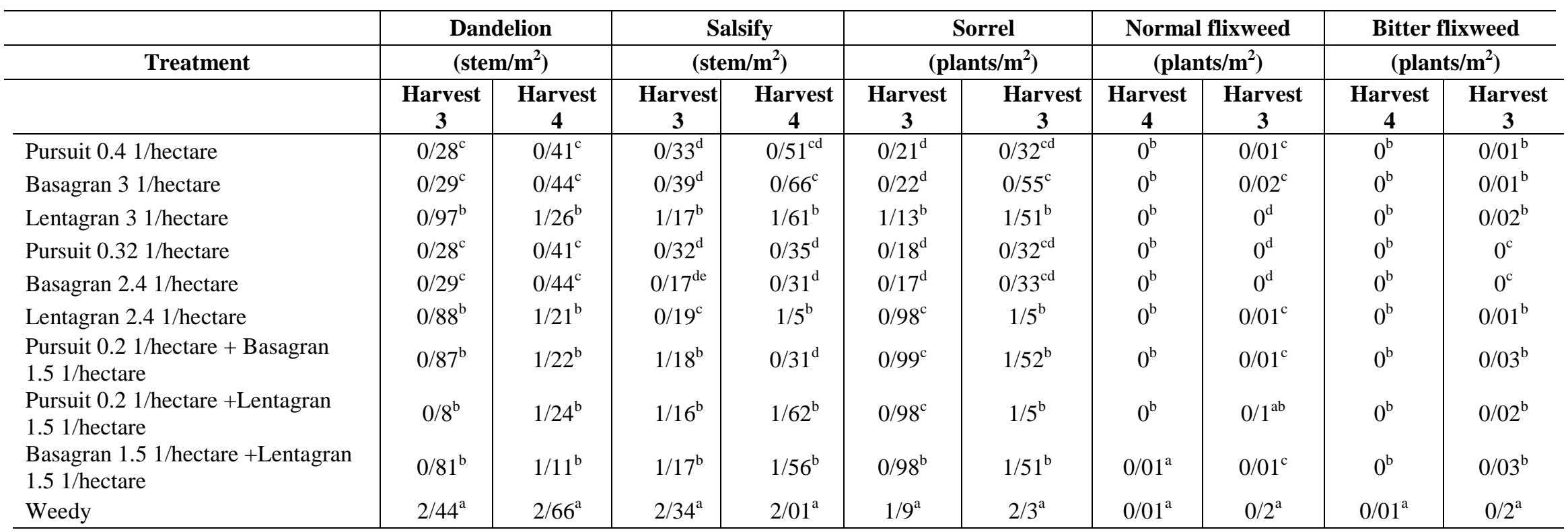


Table 9. Analysis of variance of the density and dry weight of alfalfa in each forth harvests. Ns, * and ** are insignificant and significant at confidence level of $1 \%$ and $5 \%$, respectively

\begin{tabular}{|c|c|c|c|c|c|c|c|c|c|}
\hline & & & & \multicolumn{2}{|c|}{ Mean-squares } & \multirow[b]{2}{*}{$\begin{array}{c}\text { Harvest } \\
\text { density } \\
\text { (forth) }\end{array}$} & \multirow[b]{2}{*}{$\begin{array}{c}\text { Harvest density } \\
\text { (third) }\end{array}$} & \multirow[b]{2}{*}{$\begin{array}{c}\text { Harvest } \\
\text { density } \\
\text { (second }\end{array}$} & \multirow[b]{2}{*}{$\begin{array}{l}\text { Harvest density } \\
\text { (first) }\end{array}$} \\
\hline CV & Df & $\begin{array}{c}\text { Dry weight } \\
\text { (forth harvest) }\end{array}$ & $\begin{array}{l}\text { Dry weight } \\
\text { (third) }\end{array}$ & $\begin{array}{l}\text { Dry weight } \\
\text { (second) }\end{array}$ & $\begin{array}{c}\text { Dry } \\
\text { weight } \\
\text { (first) }\end{array}$ & & & & \\
\hline Block & 3 & $144.5^{\mathrm{n} . \mathrm{s}}$ & $145.45^{\text {n.s }}$ & $139.51^{\text {n.s }}$ & $144.42^{\text {n.s }}$ & $0.44^{\text {n.s }}$ & $0.42^{\text {n.s }}$ & $0.59^{\mathrm{n} . \mathrm{s}}$ & $0.48^{\text {n.s }}$ \\
\hline Treatment & 10 & $4221.39 * *$ & $4251.22 * *$ & $4211.36^{* *}$ & $4206.33 * *$ & $751.28 * *$ & $761.51 * *$ & $736.33 * *$ & $757.26 * *$ \\
\hline Errors & 30 & 307.12 & 305.9 & 306.64 & 307.68 & 17.8 & 19.4 & 16.6 & 18.9 \\
\hline $\mathrm{CV}$ & & 5.82 & 7.22 & 6.32 & 7.37 & 6.14 & 5.82 & 6.72 & 7.31 \\
\hline
\end{tabular}


The Pursuit herbicide is a chemical treatment of the ALS family, which can be effective in broadleaf weed control. Cytogate can also increase the controlling power of this treatment, as seen in most of the harvests; this treatment could be preferred over other treatments as it appropriately controls weeds. A reduction in the density of weeds provides space for growing of alfalfa and allows it to benefit from the existing resources and conditions. In the fourth harvest, this treatment accompanied with the reduced dose Basagran treatment with associated cytogate consumption was placed in the same statistical group (Table 10). In all the four harvests, the Pursuit treatment with reduced dose and associated cytogate was determined to be the desirable treatment for increasing the alfalfa dry weight (Table 11). However, a combined treatment of Pursuit and Basagran in the second and third harvests, the Basagran treatment with reduced dose and associated cytogate consumption in the fourth harvest, and the Pursuit treatment with decreased dose and associated cytogate consumption in each harvest were found in the same statistical group and recognized to be among the best treatments for increasing the alfalfa dry weight. The results obtained from the increased pattern of the alfalfa dry weight from the first harvest to the fourth show conformity to the results from the decreased pattern of weeds, so that in the fourth harvest, the density of weed dry weight was observed to be almost the lowest, and the highest alfalfa dry weight was witnessed. In perennial alfalfa farms, in which deep-seated broadleaf weeds exist, Pursuit treatment can be effective in controlling the weeds. In addition, while the decreased dose of the herbicide can be used, such a dose reduction must be compensated for by using a cytogate surfactant so that the amount of poison drift decreases and the control percent increases.

Table 10. The average of harvest density of alfalfa during two years. In each column, the average that at least one common letter are not significantly different

\begin{tabular}{l|c|c|c|c}
\hline \multicolumn{1}{c|}{ Treatment } & $\begin{array}{c}\text { Harvest } \\
\text { density(forth) }\end{array}$ & $\begin{array}{c}\text { Harvest } \\
\text { density(third) }\end{array}$ & $\begin{array}{c}\text { Harvest } \\
\text { density(second) }\end{array}$ & $\begin{array}{c}\text { Harvest } \\
\text { density(first) }\end{array}$ \\
\hline & \multicolumn{4}{|c}{$\left(\mathrm{stem} / \mathrm{m}^{2}\right)$} \\
\hline Pursuit 0.4 1/hectare & $147 / 3^{\mathrm{c}}$ & $145 / \mathrm{1}^{\mathrm{c}}$ & $144 / 4^{\mathrm{e}}$ & $131 / 6^{\mathrm{e}}$ \\
Basagran 3 1/hectare & $133 / 3^{\mathrm{d}}$ & $129 / 7^{\mathrm{d}}$ & $130 / 1^{\mathrm{f}}$ & $118 / 96^{\mathrm{f}}$ \\
Lentagran 3 1/hectare & $97 / 8^{\mathrm{g}}$ & $98 / 9^{\mathrm{g}}$ & $98 / 2^{\mathrm{j}}$ & $89 / 90^{\mathrm{j}}$ \\
Pursuit 0.32 1/hectare & $178 / 5^{\mathrm{a}}$ & $158 / 8^{\mathrm{b}}$ & $159 / 4^{\mathrm{b}}$ & $145 / 15^{\mathrm{b}}$ \\
Basagran 2.4 1/hectare & $178 / 8^{\mathrm{a}}$ & $157 / 9^{\mathrm{b}}$ & $148 / 3^{\mathrm{d}}$ & $135 / 39^{\mathrm{d}}$ \\
Lentagran 2.4 1/hectare & $109 / 9^{\mathrm{f}}$ & $110 / 3^{\mathrm{f}}$ & $107 / 9^{\mathrm{i}}$ & $99 / 39^{\mathrm{i}}$ \\
Weed free & $178 / 9^{\mathrm{a}}$ & $179 / \mathrm{1}^{\mathrm{a}}$ & $178 / 8^{\mathrm{a}}$ & $163 / 77^{\mathrm{a}}$ \\
$\begin{array}{l}\text { Pursuit 0.2 1/hectare } \\
\text { +Basagran 1.5 1/hectare }\end{array}$ & $158 / 2^{\mathrm{b}}$ & $157 / 7^{\mathrm{b}}$ & $157 / 1^{\mathrm{c}}$ & $142 / 9^{\mathrm{c}}$ \\
$\begin{array}{l}\text { Pursuit 0.2 1/hectare } \\
+ \text { Lentagran 1.5 1/hectare }\end{array}$ & $121 / 7^{\mathrm{e}}$ & $120 / 0^{\mathrm{e}}$ & $122 / 3^{\mathrm{g}}$ & $111 / 19^{\mathrm{g}}$ \\
$\begin{array}{l}\text { Basagran 1.5 1/hectare } \\
\text { +Lentagran 1.5 1/hectare }\end{array}$ & $121^{\mathrm{e}}$ & $120 / 7^{\mathrm{e}}$ & $119 / 7^{\mathrm{h}}$ & $109 / 66^{\mathrm{h}}$ \\
Weedy & $96 / 6^{\mathrm{h}}$ & $99^{\mathrm{g}}$ & $98 / 7^{\mathrm{j}}$ & $80 / 07^{\mathrm{k}}$ \\
\hline
\end{tabular}


Table 11. The average of dry weight of alfalfa during two years. In each column, the average that at least one common letter are not significantly different

\begin{tabular}{|c|c|c|c|c|}
\hline Treatment & $\begin{array}{l}\text { Dry weight } \\
\text { (forth } \\
\text { harvest) } \\
\end{array}$ & $\begin{array}{l}\text { Dry weight } \\
\text { (third) }\end{array}$ & $\begin{array}{l}\text { Dry weight } \\
\text { (second) }\end{array}$ & $\begin{array}{c}\text { Dry weight } \\
\text { (first) }\end{array}$ \\
\hline & \multicolumn{4}{|c|}{$\left(\mathrm{g} / \mathrm{m}^{2}\right)$} \\
\hline Pursuit 0.4 1/hectare & $138 / 76^{\mathrm{d}}$ & $132 / 3^{d}$ & $132 / 7^{\mathrm{c}}$ & $117 / 61^{\mathrm{c}}$ \\
\hline Basagran 3 1/hectare & $120 / 92^{\mathrm{e}}$ & $118 / 65^{\mathrm{e}}$ & $117 / 26^{\mathrm{d}}$ & $105 / 71^{\mathrm{d}}$ \\
\hline Lentagran 3 1/hectare & $89 / 75^{\mathrm{h}}$ & $89 / 75^{\mathrm{h}}$ & $88 / 99^{\mathrm{f}}$ & $80 / 72^{\mathrm{f}}$ \\
\hline Pursuit 0.32 1/hectare & $159 / 72^{\mathrm{ab}}$ & $146 / 35^{\mathrm{b}}$ & $145 / 62^{\mathrm{b}}$ & $133 / 33^{\mathrm{ab}}$ \\
\hline Basagran 2.4 1/hectare & $162 / 88^{\mathrm{a}}$ & $143 / 24^{\mathrm{bc}}$ & $133 / 11^{\mathrm{c}}$ & $117 / 97^{\mathrm{c}}$ \\
\hline Lentagran 2.4 1/hectare & $99 / 75^{\mathrm{g}}$ & $99 / 97^{\mathrm{fg}}$ & $89 / 65^{\mathrm{fg}}$ & $91 / 75^{\mathrm{e}}$ \\
\hline Weed free & $165 / 23^{\mathrm{a}}$ & $161 / 77^{\mathrm{a}}$ & $160 / 73^{\mathrm{a}}$ & $137 / 66^{\mathrm{a}}$ \\
\hline $\begin{array}{l}\text { Pursuit } 0.2 \text { 1/hectare +Basagran } 1.5 \\
\text { 1/hectare }\end{array}$ & $149 / 62^{\mathrm{bc}}$ & $142 / 95^{\mathrm{bc}}$ & $145 / 77^{\mathrm{b}}$ & $125 / 52^{\mathrm{b}}$ \\
\hline $\begin{array}{l}\text { Pursuit } 0.2 \text { 1/hectare +Lentagran } 1.5 \\
1 / \text { hectare }\end{array}$ & $110 / 19^{f}$ & $108 / 96^{\mathrm{ef}}$ & $114 / 2^{\text {de }}$ & $104 / 77^{\mathrm{d}}$ \\
\hline $\begin{array}{l}\text { Basagran } 1.5 \text { 1/hectare +Lentagran } 1.5 \\
\text { 1/hectare }\end{array}$ & $109 / 92^{\mathrm{f}}$ & $108 / 12^{\mathrm{ef}}$ & $113 / 87^{\mathrm{de}}$ & $92 / 57^{\mathrm{e}}$ \\
\hline Weedy & $88 / 21^{\mathrm{h}}$ & $88 / 95^{\mathrm{h}}$ & $89 / 55^{\mathrm{fg}}$ & $71 / 88^{\mathrm{g}}$ \\
\hline
\end{tabular}

\section{Discussion}

In general, adjuvants greatly vary with respect to chemical structure and performance, but most of them have a hydrophilic and a lipophilic segment. Herbicides applied along with the cytogate surfactant were more efficient for weed control, as well as for an increase of the product yields, as imazethapyr herbicide along with cytogate surfactant managed to control weeds for a rate of $87.43 \%$ and increase the product yields to $93.54 \%$. Results showed that combination of herbicides can also be useful in controlling weeds in alfalfa fields and increasing product yields. Results also revealed that combination of bentazon and imazethapyr increased product yields to $94.47 \%$ and controlled weeds for a rate of $90.19 \%$. The equilibrium between the hydrophilicity and lipophilicity of adjuvants is a criterion of the relative distribution of the hydrophilic and hydrophobic components of adjuvants. This important feature has a clear influence on herbicide performance, which was clearly demonstrated in the present research. Certainly, adjuvants are extremely efficient in weed control because they facilitate the spreading of spray particles and absorption of active ingredients and improve herbicide efficiency through reducing surface tension (which was clearly demonstrated in the present study). Since the positive effect of Cytogate in increasing the efficiency of the mentioned herbicides was evaluated and effective results were obtained, it is recommended that this adjuvant should be employed in fields where the spectrum of the mentioned herbicides is used. Although the positive effect of applying Cytogate in improving weed control in fields has been proved, yet it is suggested that other adjuvants be evaluated together with other types of herbicides by researchers so that the synergistic and antagonistic effects of these adjuvants on these herbicides can be determined. 


\section{REFERENCES}

[1] Anonymous (2006b): Pursuit herbicide product label. BASF Publication No. NVA 200604-130-0232. Research Triangle Park, NC: BASF. 27.

[2] Asmus, E., Popp, C., Friedmann, A. A., Arand, K., Riederer, M. (2016): Water Sorption Isotherms of Surfactants: A Tool To Evaluate Humectancy. - Journal. Agric. Food Chem.64(26): 5310-5316.

[3] Beckie, H. J., Morrison, I. N. (1993): Effective kill of trifluralin - susceptible and resistance green foxtail (Setaria viridis) - Weed Technology (7): 15-22.

[4] Becker, R. L., Sheaffer, C. C., Miller, D. W., Swanson, D. R. (1998): Forage quality and economic implications of systems to manage giant foxtail and oat during alfalfa establishment. - J. Prod. Agric. 11: 300-308.

[5] Bradley, K. W., Hagood, E. S., Love, K. P., Heidel., R. D. (2004): Response of biennial and perennial weeds to selected herbicides and prepackaged herbicide combinations in grass pastures and hay fields. - Weed Technol. 18: 795-800.

[6] Bradley, K., Kallenbach, R., Roberts, C. A. (2010): Influence of seeding rate and herbicide treatments on weed control, yield, and quality of spring-seeded glyphosateresistant alfalfa. - Agronomy Journal 102: 751-758.

[7] Calvin, F.G., McCordick, S.A, Dietz, T.S., Kells, J.J., Leep, R.H., Everman, W.J. (2011): Effect of seeding rate and weed control on glyphosate-resistant alfalfa establishment. Weed Tech. 25(2):230-238.

[8] Campagna, G. (1995): Development and prospect of chemical weed control. Informatory fitopatologico 45(3): 52-56.

[9] Chen, X., You, X., Liu, F., Zhang, X. (2015): Low-density solvent based vortex-assisted surfactant enhanced emulsification microextraction with a home-made extraction device for the determination of four herbicide residues in river water. - Analytical Methods 22: 9513-9519.

[10] Curran, W. S., Hall, M. H., Werner, E. L. (1999): Effect of varying imazethapyr application rate and timing on yield of seedling grass-alfalfa mixtures. - J. Prod. Agric. 12: 244-248.

[11] Doll, J. D. (1984): Effects of common dandelion on alfalfa drying time and yield. - Proc. N. Cent. Weed Cont. Conf. 39: 113-114.

[12] Doll, J. D. (1986): Do weeds affect forage quality? Pages 161-170 - In: Proceedings of the 16th National Alfalfa Improvement Symposium, Fort Wayne, IN.

[13] Fischer, A. J., Dawson, J. H., Appleby, A. P. (1988): Interference of annual weeds in seedling alfalfa (Medicago sativa). - Weed Sci. 36:583-588.

[14] Ghorbani, A., Rashedmohasel, M. H., Hosseini, S. A., Mousavi, S. K., Haj mohammadnia ghalibaf, A. (2009): Sustainable management of weeds. - University of Mashhad.

[15] Giti, S., Daneshian, J., Shirani Rad, A. H., Khanjani, M. (2013a): Cytogate use in the management of weeds in alfalfa and its effectiveness in controlling of the Heteroptera. Congress on applied research in science and engineering. IAU of Qazvin. Jun 2013.

[16] Giti, S., Daneshian, J., Shirani Rad, A. H., Khanjani, M. (2013b): Cytogate application in the reduction of the reduced dose of herbicides in weed management of alfalfa fields. The Fifth Conference of weed science. Tehran University. Aug 2013.

[17] Gressel, J., Segel, L. A. (1990a): Herbicide rotation and mixture effective strategies to delay resistance. - In: Green, M. B., Lebaron, H. L., Moberg, W. K. (eds.) Managing Resistance to Agrichemical, from fundamental research to practical strategies.

[18] Gressel, J., Segel, L. A. (1990b): Modelling the effectiveness on herbicide rotation and mixture as strategies to delay preclude resistance. - Weed Technology 4: 186-198.

[19] Hall, L., Beckie, H., Wolf, T. M. (1999): How Herbicides Work - Alberta Agriculture, Food and Rural Development (Canada). 
[20] Khanjani, M. (2000): The study of controlling of integrated pest and weed to seed production of the first harvest of alfalfa in Hamadan perennial. - Research projects (unpublished), Ministry of Agriculture, registration number 3643 (dated 2008)

[21] Khanjani, M., SoleimaniPari, M. J. (2005): Integrated pest management, diseases and weeds in alfalfa in Iran. - Publication of research, education and agricultural extension.

[22] Lanini, W. T., Orloff, S. B., Vargas, R. N., Orr, J. P., Marble, V. L., Gratta, S. R. (1991): Oat companion crop seeding rate effect on alfalfa establishment, yiels and weed control. Agron. J. (83): 330-333.

[23] Lanini, W. T., Orloff, S. B., Bendixenm, W. E., Canevari, W. M., Schmiere, J. L., Ronald, N. V. (1999): Influence of oat (Avena sativa) interseeding on weed suppression in the final year of an alfalfa (Medicago sativa) stand. - Weed Technol. (13): 399-403.

[24] Lopez, J. A., Romera, J. L. (1993): Evaluacio'n de flumetsulam (Preside) en alfalfa en implantacio'n. Rafaela: INTA, Informe preliminar. $10 \mathrm{p}$.

[25] Mamnooie, E., Shimi, P. (2012): Evaluation of herbicides in weeds control of fresh Alfalfa. - Journal of weeds (8): 23-13.

[26] Marten, G. C., Sheaffer, C. C., Wyse, D. L. (1987): Forage nutritive value and palatability of perennial weeds. - Agron. J. 79: 980-986.

[27] McCarthy, J.J., O.F. Canziani, N.A. Leary, D.J. Dokken and K.S.White (eds) (2001): Climate change 2001: impacts, adaptation, and vulnerability. - Cambridge University Press, Cambridge.

[28] Meighani, F., Mirvakili, A., Jahedi, M. A., Baghestani, V., Shimi, P. (2011): Evaluation of herbicide (2,4-dichlorophenoxy ) acetic acid (Botres) based on alfalfa weed control. Weed science magazine 2(6): 67-77.

[29] Moyer, J. R. (1985): Effect of weed control and companion crop on alfalfa and sainfoin establishment, yields and nutrient composition. - Can. J. Plant Sci.65: 107-116.

[30] Myhre, C. D., Loeppky, H. A., Stevenson, F. C. (1998): Mon-37500 for weed control and alfalfa seed production. - Weed Technol. (3): 810-815.

[31] Ozkan, H. E., Reichard, D. L., Zhu, H., Ackerman, K. D. (1993): Effect of drift retardant chemical on spray drift, droplet size and spraypattern. - Berger, P. D., Devisety, B. N., Hall, F. R. (eds.) Pesticide Formulations and Application System: $13^{\text {th }}$ Volume, ASTM STP 1183, American Society for Testing and Materials, Philadelphia, PA.

[32] Raoofi, M., Giti, S. (2012): The effects of chemical pesticides on the environment pollution and soil micro-organisms in alfalfa fields. - The first national conference on environmental protection and planning. IAU of Hamadan Branch. Jan 2012.

[33] Raoofi, M., Giti, S., Atlasi Pak, V., Mahzari, S. (2013a): Assess the effect of different herbicides along with cytogate on weed control Iranian bitter flixweed, sorrel, Salsify and dandelion in alfalfa. - The second national conference on organic farming and conventional. The University of Mohaghegh Ardabili. Jun 2013.

[34] Raoofi, M., Giti, S., Daneshian, J. (2013b): Application of the flamethrower in the management of weeds in alfalfa and its effect on soil microphone. - The Fifth Conference of weed science. Tehran University. Aug 2013.

[35] Raoofi, M., Giti, S., Khanjani, M., Daneshian, J. (2013c): Evaluating the efficiency of the combined use of the herbicides to control weeds in alfalfa and its impact on the environment. - Technical University of Shahid Mofateh, Hamadan. Oct 2013.

[36] Raoofi, M., Khanjani, M., Giti, S., Daneshian, J. (2013d): Evaluating the efficiency of the flamethrower in weed management and pest control of Curculionidae in alfalfa fields. National conference on applied research in science and engineering. IAU of Takestan. Jun 2013.

[37] Raoofi, M., Giti, S., Kalhornia, H. (2014a): PC Gate and its role in protecting of the environment by reducing the use of chemical pesticides. - The National Conference of specialized research environment. Technical University of Shahid Mofateh, Hamedan. Jul 2014. 
[38] Raoofi, M., Khanjani., M., Daneshian, J., Giti, S. (2014b): Integrated Weed Management in Perennial Alfalfa (Medicago sativa L.) and theirs effects on soil's micro fauna. International Journal of Farming and Allied Sciences. (4): 430-435.

[39] Raoofi, M., Giti, S. (2015): The weeds of alfalfa farms and management methods. Tolou-e-Gharb Alvand Press.

[40] Temme, D. G., Harvey, R. S., Fawcett, R. S., Young, A. W. (1979): Effects of annual weed control on alfalfa forage quality. - Agron. J. 71: 51-54.

[41] Thill, D. C., Lish, J. M., Callihan, R. H., Bechinski, E. D. (1991): Integrated weed management-A component of integrated pest management: a critical review. - Weed Technol. 5: 648-656.

[42] Tonks, D. I., Jeffery, L. S., Webb, B. L. (1991): Response of seedling alfalfa (Medicago sativa) to four postemergence herbicides. - Weed Technol. 5: 736-738.

[43] Wilson, R. G. (1981): Weed control in established dryland alfalfa (Medicago sativa). Weed Sci. 29: 615-618.

[44] Wilson, R. G. (1997): Downy brome (Bromus tectorum) control in established alfalfa (Medicago sativa). - Weed Technol. 11: 277-282.

[45] Wilson, R. G., Burgener, P. A. (2009): Evaluation of glyphosatetolerant and conventional alfalfa weed control systems during the first year of establishment. - Weed Technology 23: 257-263.

[46] Wolfe, E. C., Southwood, O. R. (1980): Plant productivity and persistence in mixed pastures containing lucerne at a range of densities with subterranean clover or phalaris. Aust. J. Exp. Agric. Anim. Husb. 20: 189-196.

[47] Zand, E., Baghestani, M.A. (2002): Weed resistant to herbicide. - Jihad-e-Daneshgahi Press. Mashhad.

[48] Zand, A., Baghestani, M. A., Bitarafan, M., Shimi, P. (2007): Manual herbicides piet in Iran. - Mashhad University Jihad Press.

[49] Zand, A., Mousavi, K., Heydari, A. (2009): Herbicides and methods of their application with the optimization and reduction approach. - Mashhad University Jihad Press.

[50] Zand, E., Baghestani, M. A., Nezamabadi, N., Shimi, P. (2010): Aguide for herbicide in Iran. - University Press Center (In Persian) with English summary.

[51] Zand, E., Aliverdi., A., Homami, H., Heidari, A. (2012): Adjuvants, Oils, Surfactants and other additives for farm chemical. - Mashhad University Jihad Press.

[52] Zhu, H. R., Dexter, R. W., Fox, R. D., Reichard, D. L., Brazee, R. D., Ozkan, H. B. (1997): Effect of polymer composition and viscosity on droplet size of recirculated spray solution - Journal of Agricultural Engineering Research. 67(1): 35-45.

[53] Zimdahl, R. L. (2004): The effect of competition duration. - In: Zimdahl, R. L. (ed.) Weed-crop competition: A review. Ames, IA: Blackwell. 